ББК 63.4

\author{
Организация конференциии и издание материалов проведень \\ при финансовой поддержке Российского фонда фундаментальных исследований, \\ проект № 19-09-20008
}

Утверждено к печати Ученым советом ИИМК РАН

Редакционная коллегия тома I: В. А. Алёкшин, Л. Б. Кирчо (отв. редакторы),

В. П. Никоноров, В. Я. Стёганцева; В. В. Терёхина

Рецензенты: д. и. н. Л. Б. Вишняцкий, д. и. н. А. А. Выборнов

Программный комитет конференции: академик РАН, д. и. н., проф. М. Б. Пиотровский

(Государственный Эрмитаж, почетный председатель); д. и. н. В. А. Лапшин (ИИМК РАН, председатель); д. и. н. А. В. Головнёв (МАЭ РАН, сопредседатель); д. и. н. В. А. Дергачёв (Высшая антропологическая школа, Молдова, сопредседатель); д. и. н. И. Ф. Попова (ИВР РАН, сопредседатель); академик АН Республики Узбекистан, д. и. н., проф. Э. В. Ртвеладзе (сопредседатель); к. и. н. А. В. Поляков (ИИМК РАН, зам. председателя); к. и. н. В. А. Алёкшин (ИИМК РАН, зам. председателя); д. и. н. Ю. Е. Берёзкин (МАЭ РАН); Dr., Prof. Н. Бороффка (Германский археологический институт, Германия); В. С. Бочкарёв (ИИМК РАН); Dr. Э. Кайзер (Свободный университет Берлина, Германия); к. и. н. М. Т. Кашуба (ИИМК РАН); д. и. н. Л. Б. Кирчо (ИИМК РАН); к. и. н. А. В. Кияшко (Южный федеральный университет); к. и. н. П. Ф. Кузнецов (СГСПУ);

к. и. н. Н. М. Малов (СНИГУ); к. и. н. В. П. Никоноров (ИИМК РАН); Ю. Ю. Пиотровский

(Государственный Эрмитаж); д. и. н., проф. Д. Г. Савинов (Институт истории СПбГУ);

к. и. н. В. Н. Седых (Институт истории СПбГУ); к. и. н. Н. Н. Скакун (ИИМК РАН);

к. и. н. Н. Ф. Соловьёва (ИИМК РАН); к. и. н. А. И. Торгоев (Государственный Эрмитаж); к. и. н. Е. А. Черлёнок (Институт истории СПбГУ)

Организационный комитет конференции: к. и. н. А. В. Поляков (ИИМК РАН, председатель);

к. и. н. В. А. Алёкшин (ИИМК РАН, зам. председателя); В. С. Бочкарёв (ИИМК РАН); ); к. и. н. М. Т. Кашуба (ИИМК РАН); д. и. н. Л. Б. Кирчо (ИИМК РАН);

А. И. Климушина (ИИМК РАН, отв. секретарь); к. и. н. В. П. Никоноров (ИИМК РАН); Ю. Ю. Пиотровский (Государственный Эрмитаж); В. Я. Стёганцева (ИИМК РАН); В. В. Терёхина

(ИИМК РАН, МАЭ РАН, отв. секретарь); к. и. н. Е. С. Ткач (ИИМК РАН); И. Ж. Тутаева (Государственный Эрмитаж); к. и. н. Е. А. Черлёнок (Институт истории СПбГУ)

Древности Восточной Европы, Центральной Азии и Южной Сибири в контексте связей и взаимодействий в евразийском культурном пространстве (новые данные и концепции): Материалы Международной конференции, 18-22 ноября 2019 г., Санкт-Петербург. Т. I. Древняя Центральная Азия в контексте евразийского культурного пространства (новые данные и концепции). К 90-летию со дня рождения патриарха евразийской археологии Вадима Михайловича Массона. - СПб.: ИИМК РАН, Невская Типография, 2019. — 291 с.

ISBN 978-5-907053-34-2

DOI 10.31600/978-5-907053-34-2 


\title{
THE STRUCTURE OF “PANJMANOR” AT KALA-I KUKHNA (KARON) IN DARWAZ
}

\section{Larisa O. Smirnova}

The State Hermitage Museum, St. Petersburg, Russia

Keywords: "Panjmanor", Darwaz, Chor Minor, Bukhara, Charminar, Hyderabad, mosque.

The paper expresses doubt about the Kushan-period dating of the "Panjmanor" structure discovered at Kala-i Kukhna (Karon) in Tajikistan, which was proposed by the director of the excavations, Yu. Ya. Yakubov. The present author dates the structure to the $15^{\text {th }}$ century.

\section{DECORATIVELY CUT NARROW RIDGES OF ONE TYPE OF SASANIAN HELMETS AS A MARKER OF CONTACTS BETWEEN IRAN, CENTRAL ASIA AND EASTERN EUROPE}

\author{
Adam Lech Kubik \\ University of Siedlce, Siedlce, Poland
}

DOI: 10.31600/978-5-907053-34-2-203-205

Keywords: arms and armour, Helmets, Sasanian Iran, Central Asia, Eastern Europe, Nomads.

The decoratively cut edges of ridges constitute an evident eastern borrowing, which appear in Iran, Central Asia and Eastern Europe in Sasanian period. While the mere appearance of decorative cut-outs on segments cannot be the basis for the dating of Euro-Asiatic helmets (Бобров, Худяков 2006), some specific forms allow for the grouping of findings and their chronology (Kubik 2017: 33-42; Kubik, Nicolle 2018: 19-20). In the following paper current author will examine a number of findings from the area of Greater Iran, Central Asia and Eastern Europe with the type of decorative cut-outs that first appeared on the Iron and copper alloy helmet with remains of iron ring-mail neck-guard stated to be from Kuyunjik, suggesting that it was found during Layard's excavations of Nineveh, Northern Iraq, in late $19^{\text {th }}$ century (James 1986: 118-119; Nicolle 1996: Fig. 34g), currently held in the British Museum (BM. 22495). The author is familiar with more findings with similar form of cut-outs visible on the edges of segments. Second find of such helmet came from the David Collection, Kopenhagen (Inv. nr. 24/2005). The helmet itself is of a fourpiece spangenhelme construction, where the main triangle-shaped pieces of the main bowl are conjoined by decorative, spade-form ridges (Kubik 2018; Kubik, Nicolle 2018). According to the David Collection Museum, this helmet was discovered in what is now Iranian territory but was bought from a private collection so the precise location of the find is unknown. Third, similar in construction, came from Perm region, Russia, currently held in Perm Museum, firstly published by M. V. Gorelik (Горелик 2002: 75). Fourth was discovered in Ryelka cemetery and firstly published by L. A. Chindina (Чиндина 1977: рис. 10), currently held in Tomsk University Museum. All of those helmets share some common characteristic: the rivets on the sides of the ridges are placed in vertical lines and grouped in three groups of one (with frontal exception) and there are two decorative cuts between these groups of rivets. We can also observe such decorative cut-outs on segments of the mentioned spangenhelme type helmet in the scenes depicted in the Hall of the Ambassadors of the Afrāsiāb painting (Kubik 2017: rys. 58), date to the mid. - 3/4 of the $7^{\text {th }}$ century. Such form of decorative cut-outs could be observed also on the segments of later helmet constructions (up to the $9^{\text {th }}$ century very beginning of the $10^{\text {th }}$ century), for example on finds from Diurso cemetery in Krasnodar Krai or on the helmet discovered close to the village Moldovanovskoe, Krasnodar Krai territory. We can state that in the $7^{\text {th }}-9^{\text {th }}$ century on the territory between current South 


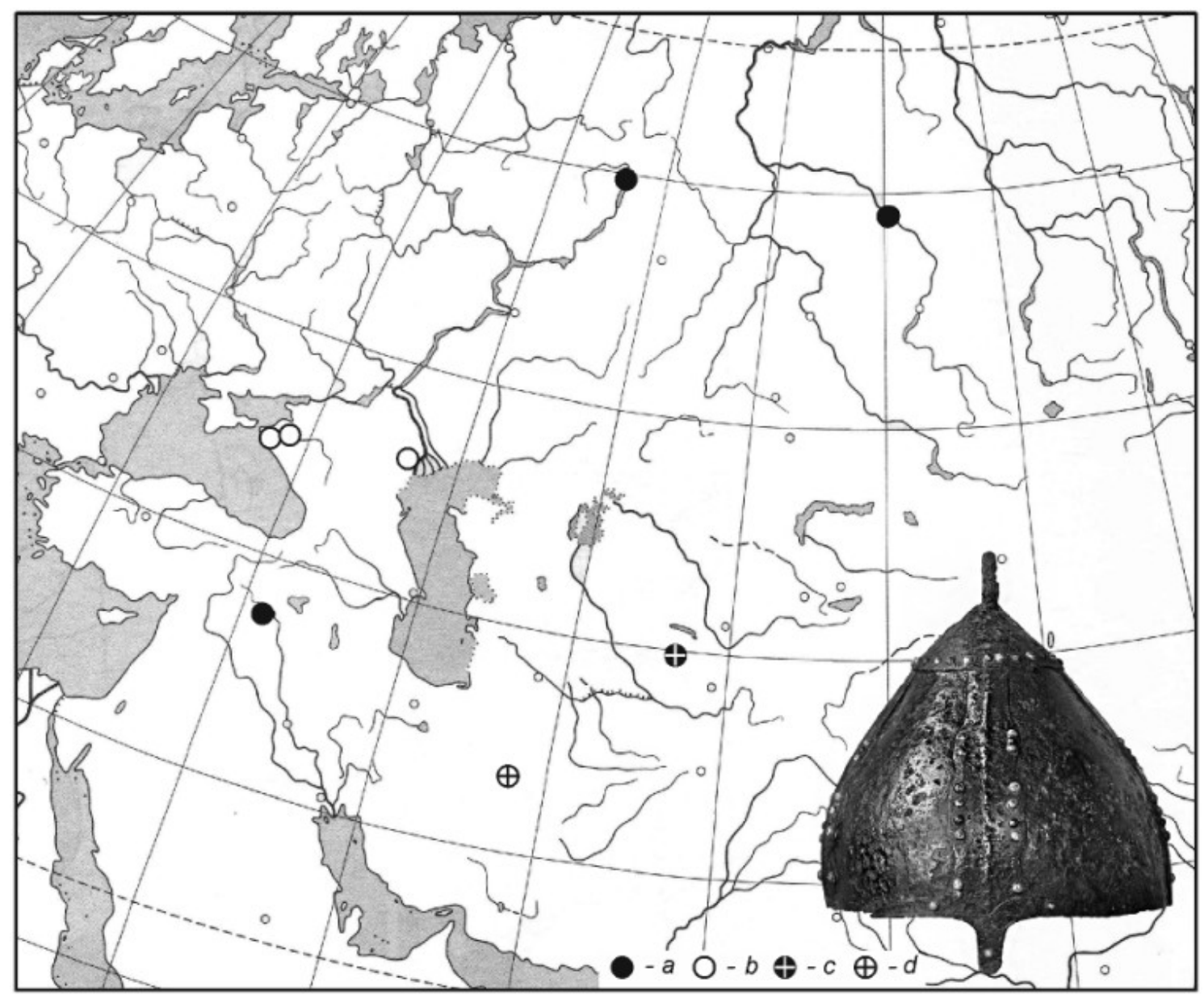

Fig. 1. A map with marked finding sites of helmets with Nineveh type cut-outs: $a$ - early Nineveh type helmets; $b$ - later forms; $c$ - depicted helmet; $d$ - the David Collection helmet hypothetical location

Eastern Russia, Central Asia and Iran such decorative cut-outs were quite common form of helmet decoration and that particular form of helmet decoration can be basis for the dating of Euro-Asiatic helmets.

In addition a map (Fig. 1) with marked finding sites of helmets with Nineveh type cut-outs (black dot - early Nineveh type helmets, red dot - later forms, violet dot — depicted helmet, blue dot - the David Collection helmet hypothetical location).

\section{References}

Бобров Л. А., Худяков Ю. С. 2006. Пластины-накладки с вырезным краем на средневековых схемах степной полосы Евразии и прилегающих территорий // Вестник Новосибирского ГУ. Серия: история, филология 5. 3. Археология и этнография. С. 87-105.

Горелик М. В. 2002. Армия монголо-татар X-XIV веков, воинское искусство, оружие, снаряжение. М.

Чиндина Л. А. 1977. Могильник Рёлка на средней Оби. Томск

James S. 1986. Evidence from Dura-Europos for the Origins of Late Roman Helmets. In: Syria. Annèe 63. P. 107-134.

Kubik A. L. 2017. Hełmy Azji Południowo-Zachodniej pomiędzy VI-VIII w. n. e. zarys problematyki. Siedlce. 
Kubik A. L. 2018. The Kizil Caves as an terminus post quem of the Central and Western Asiatic pear-shape spangenhelm type helmets The David Collection helmet and its place in the evolution of multisegmented dome helmets. In: Historia i Świat. 7. P. 141-156.

Kubik A. L., Nicolle D. 2018. The helmet from Multa river reconsidered // Двуреченская О. В. (ред.). Военная археология. М. Вып. 4. С. 17-30.

Nicolle D. 1996. Sassanian Armies. The Iranian Empire early $3^{\text {rd }}$ to mid $7^{\text {th }}$ century AD. Stockport.

\section{ФИГУРНО ВЫРЕЗАННЫЕ УЗКИЕ ГРЕБНИ ОДНОГО ТИПА САСАНИДСКИХ ШЛЕМОВ КАК СВИДЕТЕЛЬСТВО КОНТАКТОВ МЕЖДУ ИРАНОМ, ЦЕНТРАЛЬНОЙ АЗИЕЙ И ВОСТОЧНОЙ ЕВРОПОЙ}

\section{А. Л. Кубик}

Естественно-гуманитарный университет в Седльие, Факультет истории и международньх отномений, Седльще, Польша

Ключевые слова: оружие и доспехи, илемь, раннее средневековье, сасанидский Иран, Средняя Азия, Восточная Европа, кочевники.

В работе рассматривается ряд шлемов из Ирана, Центральной Азии и Восточной Европы, которые отличаются фигурно вырезанными узкими конькообразными накладками на стыки сегментов, формирующих тулью боевых оголовий. Сделан вывод, что в VII-IX вв. н. э. на указанных территориях такие декоративные вырезы были довольно распространенной формой украшения шлемов, что, в свою очередь, может служить основой для датировки раннесредневековых головных доспехов Евразии. 